\title{
The ecological requirements of caddisflies larvae (Insecta: Trichoptera) and their usefulness in water quality assessment of a river in south-west Romania
}

\author{
M. Pirvu ${ }^{(1)}$, O. Pacioglu ${ }^{(2) \star}$ \\ Received July 6, 2012 \\ Revised October 20, 2012 \\ Accepted December 7, 2012
}

\begin{abstract}
Key-words: caddisflies, Jiu River, polyhedral diagrams, pollution, Romania

This survey analyzed the eco-physiological requirements of caddisflies assemblages in Jiu River (south- west Romania). The output revealed that the communities are driven by a synergic combination of natural factors and pollutants. Their ecological profiles are diverse and the degree of tolerance is related to a decrease of water quality over a longitudinal gradient, overlapped with natural variation of physic-chemical factors. The assemblage is dominated by hydropsychids, very tolerant to anthropogenic disturbances, and two other communities separated by large distances (characteristic of headwaters and of lowland areas, respectively) that do rather reveal stronger affinities to the microhabitat requirements then to water pollution. Polyhedral diagrams were employed in order to reveal caddisflies larvae tolerances/intolerances to environmental parameters, in order to test their usefulness for local areas and less numerous samples, as frequently encountered in routine surveys.
\end{abstract}

\section{ABSTRACT}

\section{RÉSUMÉ}

Les exigences écologiques des larves de trichoptères (Insecta : Trichoptères) et leur utilité dans l'évaluation de la qualité de l'eau dans le sud-ouest de la Roumanie

Mots-clés : trichoptères, rivière Jiu, diagrammes polyédriques, pollution, Roumanie

\begin{abstract}
Cette étude a analysé les exigences éco-physiologiques des communautés de trichoptères dans la rivière Jiu (sud-ouest de la Roumanie). Le résultat a révélé que les communautés sont induites par des combinaisons synergiques de facteurs naturels et de polluants. Leurs profils écologiques sont divers et le degré de tolérance est lié à une diminution de la qualité de l'eau sur une gradient longitudinal, combinée à la variation naturelle des facteurs physico-chimiques. L'assemblage est dominé par des hydropsychidés, très tolérants aux perturbations d'origine anthropique, et deux autres communautés séparées par une grande distance (caractéristiques des eaux d'amont et des zones de plaine, respectivement) qui révèlent plutôt de fortes affinités avec les conditions du microhabitat, qu'à la pollution de l'eau. Des diagrammes polyédriques ont été utilisés pour mettre en évidence les tolérances / intolérances des larves de trichoptères aux paramètres environnementaux, afin de tester leur utilité pour les zones réduites et des échantillons moins nombreux, comme c'est le cas dans les suivis de routine. L'indice biotique $(\mathrm{BI})$ a révélé une détérioration de la qualité de
\end{abstract}

(1) Department of Biology, West University of Timişoara, Faculty of Chemistry, Biology, Geography, Timişoara, Romania

(2) Centre for Research in Ecology, Roehampton University, School of Human and Life Sciences, Whitelands College, London, UK

* Corresponding author: O.Pacioglu@roehampton.ac.uk 
l'eau sur un profil longitudinal, ce qui prouve la possibilité d'utiliser un seul groupe de macro-invertébrés dans l'évaluation de la qualité de l'eau, basée sur une petite quantité de données (60) et des sites d'échantillonnage (5).

\section{INTRODUCTION}

The rivers have been massively impacted by human induced disturbances all over the world. Mainly the abiotic factors with disturbance regime determine the composition and functionality of macroinvertebrates communities (Camargo et al., 2011; Resh et al., 1988; Townsend et al., 1997; Wildsmith et al., 2011). The River Continuum Concept (Vanotte et al., 1980), as the River Habitat Template (Townsend and Hildrew, 1994) relates the functional groups of macroinvertebrates to gradients of environmental stability, as their replacement on a longitudinal gradient. Such a mixture of life history strategies, habitat requirements, as the tolerance or sensitivity to pollution makes broader statements, very often outside a local scale, very difficult to interpret (Hildrew, 1986; MacCausland and McTammany, 2007; Usegglio-Polaterra et al., 2000).

The caddisflies represent one of the most widely used macroinvertebrates in river quality assessments, along with the mayflies and stoneflies, and the most up to date statistical packages are using them as one of the main focus groups (e.g. RIVPACS, AusRivAS) (Castillo et al., 2006; Shiels, 2010; Wright et al., 2000). One of the main reasons for their usefulness can be found in the extremely widespread distribution in every type of aquatic habitat, as in their noticeable frequency amid freshwater insects (Basaguren and Orive, 1990; Illie and Botosãneanu, 1963; Mackay, 1984).

Nevertheless, the attempt of classifying the water quality of a stream based solely on a single group of invertebrates was approached so far only erratically and by only a handful of studies (Bonada et al. 2004; Dohet, 2002; Fairchild and Holomezki, 2002; Resh, 1992). Previous investigations employed large data sets in order to counterbalance many inconveniences encountered during routine surveys, e.g. extrapolations for wider geographical and geological areas (Bonada et al., 2005) that could concur and overlap with natural induces regimes. The investigation of the autecological requirements of caddisflies from a longitudinal perspective in lotic ecosystems, and more important, their use as a single group in the attempt to test their usefulness as indicators of water quality was never approached on the Romanian territory. The caddisflies have been described previously as an ideal group for freshwater impact assessments, and this survey aims in describing the eco-physiologic requirements of caddisflies larvae in a stream impacted by increasing anthropogenic pressures from the headwaters towards lowland areas.

Therefore, the testing hypothesis is that the community of caddisflies will comprise different assemblages as a result of a synergic impact between the variation of natural variables over a longitudinal profile and their overlap with pollutants. Therefore, we predict that identifiable abiotic factors with the help of mainly descriptive multivariate statistics will perform as good predictors in establishing the range of environmental parameters, as of control factors of the caddisflies presence/absence along the longitudinal transect of the studied river.

\section{MATERIALS AND METHODS}

The River Jiu lies in the southwest of Romania and represents an important tributary of the Danube. Historically, the entire catchment used to be exploited for charcoal, the mining areas comprising a large surface of the actual drainage basin. Nowadays, the mining activities ceased only partially, with remnant ash pits still visible a few meters further away from the main stem of the river, amplified by a few still active mining points. This, and several water works, overlapped with the activity of sewage treatment plants and industrial centres 


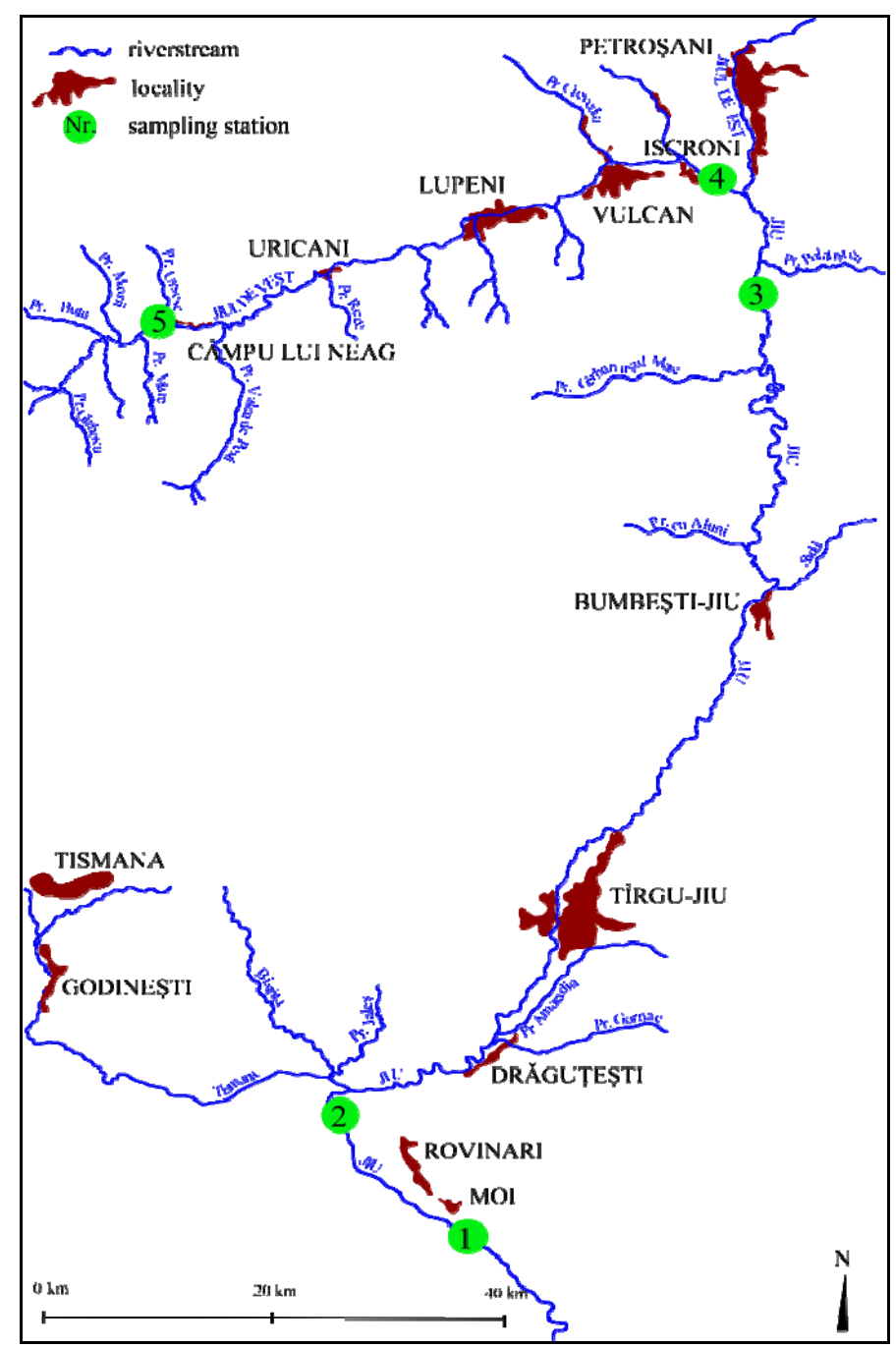

Figure 1

Map of Jiu River catchments with its main tributaries and sampling sites.

\section{Table I}

GIS coordinates and altitude of sampling sites.

\begin{tabular}{|l|c|c|c|}
\hline Sampling site & Latitude $N$ & Longitude E & Altitude \\
\hline S1 & $44^{\circ} 53^{\prime} 41.6542^{\prime \prime}$ & $23^{\circ} 12^{\prime} 24.7330^{\prime \prime}$ & $170 \mathrm{~m}$ \\
\hline S2 & $44^{\circ} 57^{\prime} 1.6998^{\prime \prime}$ & $23^{\circ} 08^{\prime} 2.0296^{\prime \prime}$ & $180 \mathrm{~m}$ \\
\hline S3 & $45^{\circ} 16^{\prime} 51.0644^{\prime \prime}$ & $23^{\circ} 23^{\prime} 34.8419^{\prime \prime}$ & $588 \mathrm{~m}$ \\
\hline S4 & $45^{\circ} 22^{\prime} 6.2047^{\prime \prime}$ & $23^{\circ} 22^{\prime} 7.4284^{\prime \prime}$ & $628 \mathrm{~m}$ \\
\hline S5 & $45^{\circ} 18^{\prime} 12.3923^{\prime \prime}$ & $23^{\circ} 03^{\prime} 9.8449^{\prime \prime}$ & $980 \mathrm{~m}$ \\
\hline
\end{tabular}

(e.g. quarries, power plants) are posing serious threats for local water quality (Cupşa et al., 2010; Dumbravã-Dodoacã and Petrovici, 2010).

Quantitative samples were collected within the period May 2009 - February 2010, four times a year, from two rivers (same catchment): R. Jiu, main stem (S5-S3, Figure 1) and its main tributary, the Western Jiu (S2-S1, Figure 1). The GIS coordinates of sampling sites, along with their altitude are stated in Table I. The sites were selected along a longitudinal gradient, the first station being situated in the headwaters $\left(S_{5}\right)$, representative for a control, pristine site. The sites $\mathrm{S}_{4}$ and $\mathrm{S}_{3}$ were selected before and respectively after the confluence of the main stem with its most western tributary, downstream the City of Petrosani, in order to reflect the downstream 
Table II

Mean and standard error of the mean $(1 \pm S E)$ for the physic-chemical parameters measured on each site.

\begin{tabular}{|c|c|c|c|c|c|}
\hline $\begin{array}{l}\text { Physic-chemical } \\
\text { parameters }\end{array}$ & S1 & s2 & s3 & $\$ 4$ & S5 \\
\hline $\begin{array}{l}\text { Suspended } \\
\text { sediment } \\
\left(\mathrm{mg} \cdot \mathrm{L}^{-1}\right)\end{array}$ & $53.2 \pm 0.8$ & $33.7 \pm 0.6$ & $44.20 \pm 0.9$ & $54.5 \pm 0.9$ & $20.5 \pm 0.4$ \\
\hline $\mathrm{SO}_{4}\left(\mathrm{mg}-\mathrm{S} \cdot \mathrm{L}^{-1}\right)$ & $49.2 \pm 2.7$ & $31.2 \pm 2.1$ & $35.4 \pm 2.3$ & $50.3 \pm 0.7$ & $25.8 \pm 0.6$ \\
\hline $\begin{array}{l}\text { Conductivity } \\
\left(\mu \mathrm{S} \cdot \mathrm{L}^{-1}\right)\end{array}$ & $191.5 \pm 17.1$ & $185.8 \pm 9.9$ & $167 \pm 8.7$ & $99.2 \pm 3.7$ & $96.8 \pm 1.4$ \\
\hline BOD5 (mg. $\left.\mathrm{L}^{-1}\right)$ & $3.6 \pm 0.3$ & $4.4 \pm 0.5$ & $4.7 \pm 0.7$ & $1.1 \pm 0.1$ & $1.5 \pm 0.07$ \\
\hline $\begin{array}{l}\text { Total Organic } \\
\text { Carbon }\left(\mathrm{mg} \cdot \mathrm{L}^{-1}\right)\end{array}$ & $1.58 \pm 0.8$ & $1.07 \pm 1.4$ & $1.06 \pm 2.9$ & $0.8 \pm 0.4$ & $0.25 \pm 0.5$ \\
\hline Alkalinity $\left(\mathrm{mg} \cdot \mathrm{L}^{-1}\right)$ & $1.3 \pm 0.01$ & $1 \pm 0.06$ & $0.9 \pm 0.05$ & $0.8 \pm 0.02$ & $0.9 \pm 0.1$ \\
\hline $\mathrm{NH}_{4}\left(\mathrm{mg}-\mathrm{N} \cdot \mathrm{L}^{-1}\right)$ & $0.15 \pm 0.007$ & $0.11 \pm 0.02$ & $0.13 \pm 0.008$ & $0.15 \pm 0.03$ & $0.04 \pm 0.01$ \\
\hline $\mathrm{NO}_{2}\left(\mathrm{mg}-\mathrm{N} \cdot \mathrm{L}^{-1}\right)$ & $0.08 \pm 0.01$ & $0.08 \pm 0.01$ & $0.1 \pm 0.01$ & $0.006 \pm 0.0009$ & $0.03 \pm 0.009$ \\
\hline $\mathrm{NO}_{3}\left(\mathrm{mg}-\mathrm{N} \cdot \mathrm{L}^{-1}\right)$ & $2.9 \pm 0.3$ & $3.2 \pm 0.3$ & $1.8 \pm 0.34$ & $1.02 \pm 0.12$ & $0.4 \pm 0.11$ \\
\hline $\mathrm{PO}_{4}\left(\mathrm{mg}-\mathrm{P} \cdot \mathrm{L}^{-1}\right)$ & $0.08 \pm 0.01$ & $0.11 \pm 0.01$ & $0.15 \pm 0.03$ & $0.004 \pm 0.0004$ & $0.01 \pm 0.001$ \\
\hline $\begin{array}{l}\text { Water } \\
\text { temperature }\left({ }^{\circ} \mathrm{C}\right)\end{array}$ & $10.2 \pm 1.7$ & $10.7 \pm 1.8$ & $9.3 \pm 1.4$ & $10.1 \pm 1.78$ & $6.9 \pm 1.9$ \\
\hline $\begin{array}{l}\text { Oxygen } \\
\text { (\% saturation) }\end{array}$ & $85 \% \pm 0.02$ & $6 \% \pm 0.02$ & $10 \% \pm 0.04$ & $0.9 \pm 0.03$ & $134 \% \pm 0.17$ \\
\hline Water flow $\left(\mathrm{m} \cdot \mathrm{s}^{-1}\right)$ & $7.4 \pm 0.3$ & $7 \pm 0.33$ & $9.8 \pm 0.3$ & $8.4 \pm 0.5$ & $10.6 \pm 0.1$ \\
\hline $\mathrm{pH}$ & $8.32 \pm 0.12$ & $7.5 \pm 0.06$ & $8.3 \pm 0.07$ & $7.9 \pm 0.1$ & 7 \\
\hline
\end{tabular}

influences of local sewage treatment plants. The site $S_{2}$ was chosen after the confluence with a cleaner tributary (River Tismana) and the $\mathrm{S}_{1}$, the further away site, downstream the City of Rovinari, in order to illustrate one of the most degraded river stretches from this watershed due the combination of aforementioned human induced disturbances (Dumbravã-Dodoacã and Petrovici, 2010). On each visit were taken three replicates of biological, physic-chemical measurements as of water samples, resulting altogether in 60 replicates of each kind. The biological samples were preserved in $8 \%$ formaldehyde. The invertebrates were collected from every site in three replicates with a Surber sampler (surface $1073 \mathrm{~cm}^{2}$ and $250 \mu \mathrm{m}$ mesh size) and their abundance was estimated $/ \mathrm{m}^{2}$. The water temperature, dissolved oxygen, conductivity, $\mathrm{pH}$ and flowing velocity were measured in situ, with a specialized probe (350i SET type multimeter). Three recipients of water samples (each of 1 I volume) were sent to the local laboratory for water quality in order to be analyzed for: suspended sediments in the water column, sulphates, biological oxygen demand $\left(\mathrm{BOD}_{5}\right)$, total organic matter as free dried ash (TOC), alkalinity, $\mathrm{N}$ species (nitrites, nitrates, ammonia) and phosphate concentrations (Table II). The caddisflies were sorted in the laboratory with the aid of a dissecting microscope and identified afterwards to species level (Waringer and Graf, 1997; Wallace et al., 2003).

Each site comprised one riffle with similar dimensions: $18.3 \pm 2.31 \mathrm{~m}$ wide, respectively $0.28 \pm$ $0.08 \mathrm{~m}$ deep in average. The type of substratum varied from boulders up to sand and ooze (personal observations).

Apart from $\mathrm{pH}$, all the physic-chemical parameters were $\log (x+1)($ Table II) and tested for normality (Kolmogorov-Smirnof test). After the assumptions of normality were met, a PCA analysis was applied in order to reveal the variance amid sampling sites, and the eigenvalues of the first two axes, along with their percentage of variance were stated and checked for eligibility, according to the "broken stick" model (Shaw, 2003) (Table III) (Figure 2).

The caddisflies densities were $\log (x+5)$, checked for normality and the relationship between their abundance and environmental parameters estimated with the help of pCCA (partial Canonical Correspondence Analysis) (CANOCO 4.5 for Windows). The significance of 


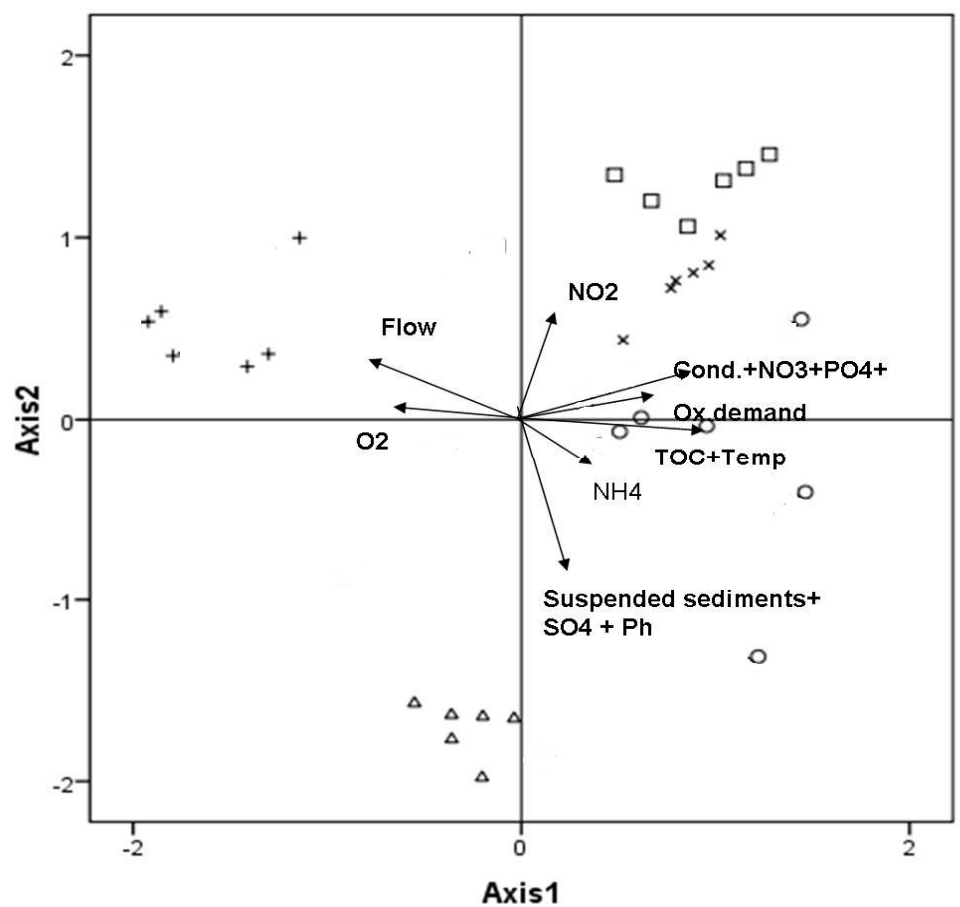

$$
\begin{gathered}
\text { Sampling site } \\
\text { Os1 } \\
\square \mathrm{s} 2 \\
\times \mathrm{s} 3 \\
\triangle \mathrm{s} 4 \\
+\mathrm{s} 5
\end{gathered}
$$

\section{Figure 2}

PCA ordination of physic-chemical parameters along sampling sites. The physic-chemical variables are analysed along an upstream-downstream gradient along the first axis (water velocity, dissolved oxygen, conductivity, nitrates, phosphates, total organic carbon, temperature and biological oxygen demand). Along the second axis there is a variation between sampling sites S2 and S4 (nitrites, suspended sediments, sulphates and $\mathrm{pH}$ ).

\section{Table III}

Eigenvalues, explained and cumulative percentages explained by the first two axes of the PCA ordination.

\begin{tabular}{|c|c|c|c|}
\hline & Eigenvalues & Explained percentage & Cumulative percentage (\%) \\
\hline Axis 1 & 5.7 & 40.7 & 40.7 \\
\hline Axis 2 & 2.44 & 17.5 & 58.3 \\
\hline
\end{tabular}

environmental parameters in explaining the existence of taxa was checked upon a Monte Carlo test (999 permutations) (Shaw, 2003). Due the overlap and collinearity between natural and human induced variability in the environmental data sets, two partial CCA were needed (Figures 3 and 4). After selecting the appropriate environmental variables, a stepwise linear regression was applied for each species in order to retain the variables that are the best predictors in explaining their abundance. A TWINSPAN analysis (DECORANA program), was applied in order to retain those taxa that could be used as "indicator" species (Shaw, 2003) (Figure 5).

A more qualitative approach, based on weighted means was applied, following the recommendations of Bonada et al. (2004), in order to see if the findings from larger data sets are applicable for more local areas and smaller data sets. Therefore, following the recommendations of ter Braak and Barendregt (1986) and those of Birks et al. (1990), an optimum and tolerance values were calculated for each taxa considering those variables found as significant after the application of the liner regression models. The values for tolerances/each taxa were standardized to values below unit, by dividing them to the highest calculated value (Bonada et al., 2004). Afterwards, a polyhedral diagram (Figures 6a-6c) was constructed by orientating the tolerance values for the selected environmental parameters towards a common point at equal angles, summing altogether $180^{\circ}$. The parameters related to pollution 


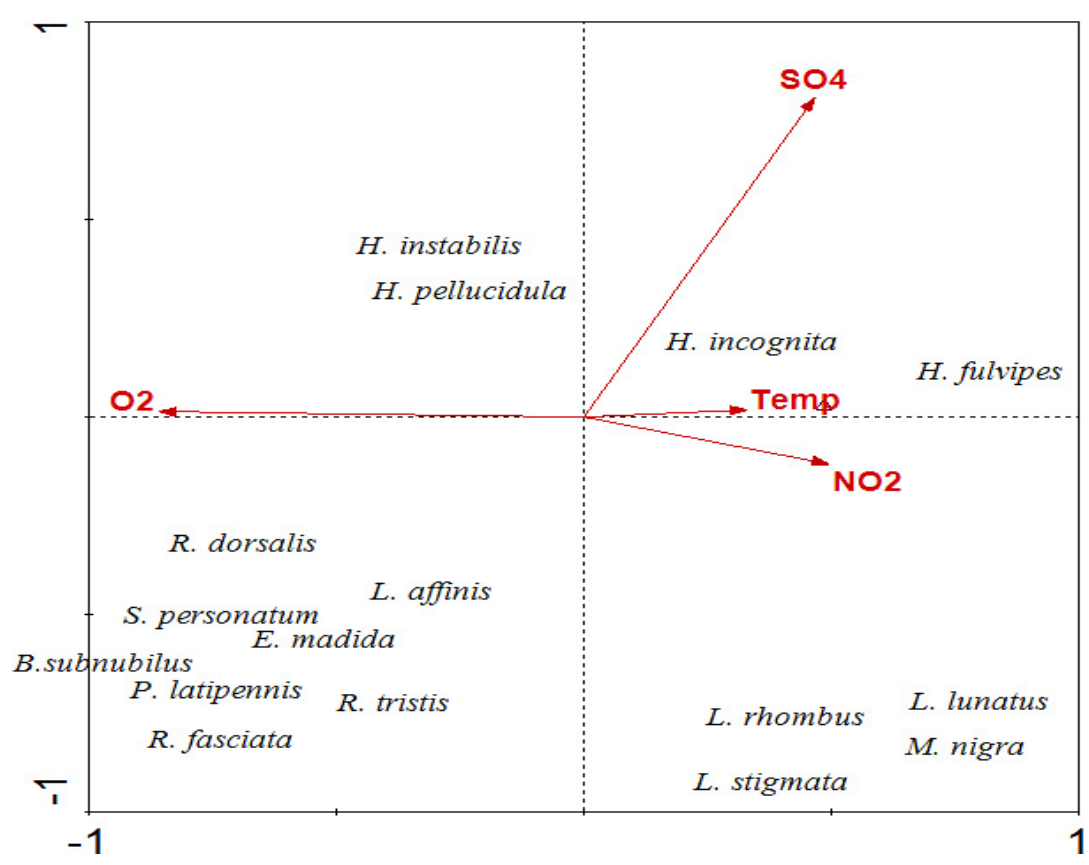

\section{Figure 3}

Partial CCA ordination plot of caddisflies species mainly as a result of chemical pollution. The natural decrease from headwaters to lowland sites of temperature and oxygen is depicted along the first axis, revealing a preference for different groups of caddisflies. The variation of sulphates along the second axis separates common hydropsychids from other two species confined more downstream.

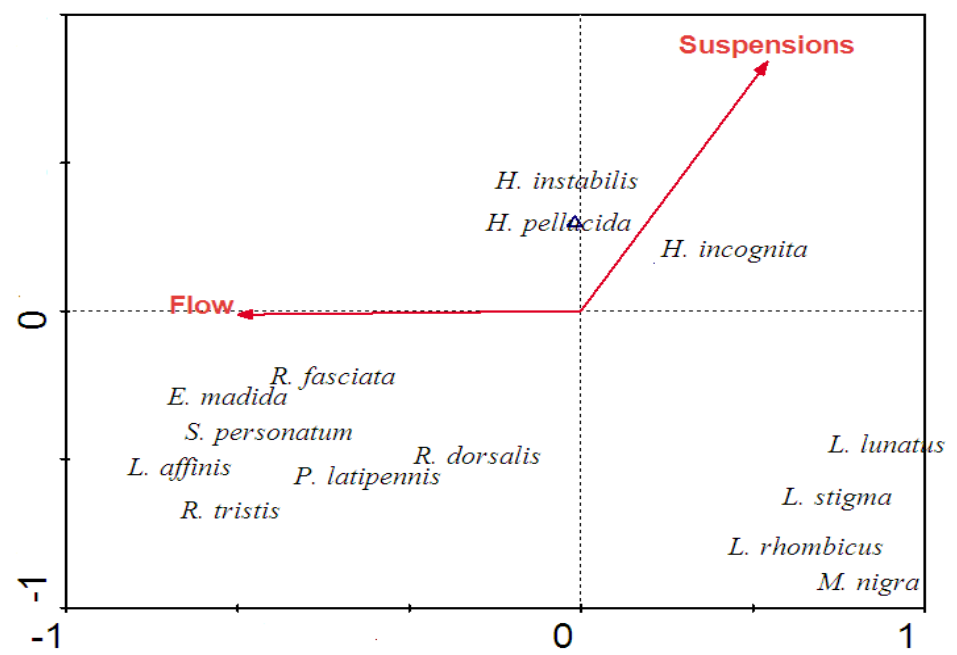

Figure 4

Partial CCA based only on water velocity and suspended sediments in water column. The water velocity decreases along the river longitudinal profile (first axis), with same groups as above (Figure 3) separated by a long distance. The hydropsychids reveal a preference for high suspended organic loads (second axis).

(sulphates, nitrites, phosphates and oxygen demand-CBO${ }_{5}$ ) were oriented with their origins towards the outer side of the diagram. The variables related to pristine conditions (dissolved oxygen, water velocity) were drawn from 0 to 1 inside (Bonada et al., 2004). The degree of tolerance/intolerance was estimated at a qualitative level by unifying the upper and lower limits of tolerances and colouring the unified area. The shadowed areas represent the degree of tolerance and the white spaces (area within the diagram) the degree of intolerance. In some cases, because of the large value of the lower/ upper limits, there are non shaded 


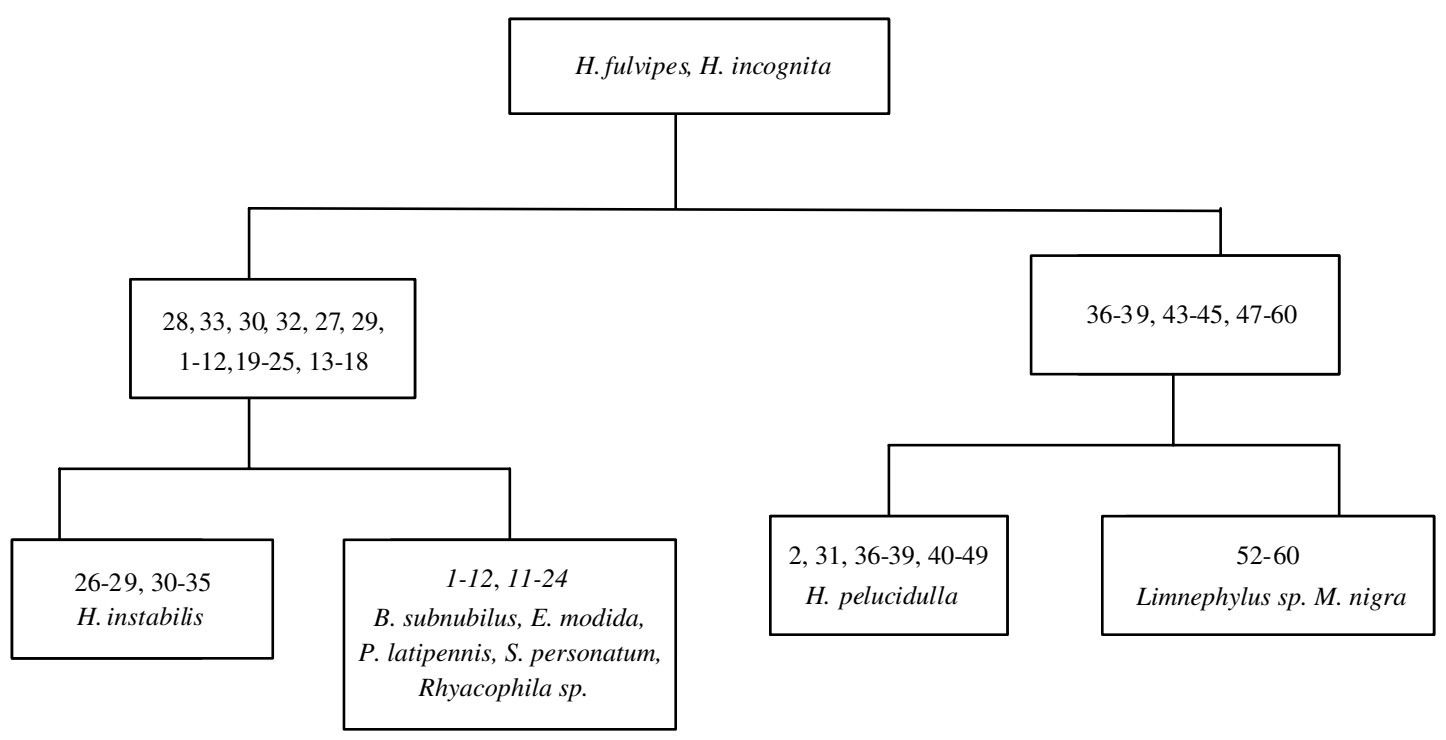

\section{Figure 5}

TWINSPAN dendrogram clusters of taxa (comments in text).

areas, indicating that the taxa should be infrequent in values below/above these conditions. The diagrams were clustered in groups, according to the clades separated by the TWINSPAN dendrogram (Figure 5).

\section{RESULTS}

The first axis of the PCA ordination (Figure 2) is a consequence of an altitudinal transect from the headwaters $\left(S_{5}\right)$ towards the downstream sites, and represents a decrease of annual mean water velocity, dissolved oxygen, and an increase in temperature, associated refractory organic matter, oxygen demand, alkalinity, conductivity, $\mathrm{N}$-compounds (nitrites, nitrates, ammonia) and phosphates as a direct consequence of pollution, as revealed by their means across sampling sites (Table II). The second axis is mainly an effect of nitrites (higher in S2) and higher concentration of sulphates, suspended solids and $\mathrm{pH}$ for $\mathrm{S}_{4}$. Therefore, the heterogeneity of the water physic-chemistry along the sites is reflected along the both axes as a potential suite of "disturbances" along a longitudinal path. Both axes explain a variance of $58.3 \%$ of physic-chemicals between sites (Table III), the main axis explaining $40.7 \%$.

The partial CCA ( $\mathrm{pCCA}$ ) ordination plot of caddisflies larvae and chemical parameters (Figure 3) illustrates the factors found eligible in explaining the variability of taxa: the dissolved oxygen, temperature, nitrites and sulphates in a proportion of $70 \%$ (Monte Carlo test, 999 permutations). The caddisflies reflect a strong affinity for high and low altitude sites, as for pristine and polluted areas of the river. The species from genus Rhyacophila sp., Sericostoma personatum, Ecllisopteryx madida, Potamophylax latipennis, Limnephilus affinis have a clear affinity for highly oxygenated and pristine headwaters. The species from genus Hydropsyche $\mathrm{sp}$. are generalist taxa that have a high tolerance for high levels of sulphates and a third group, represented by species from genera Limnephylus sp. and Mistacydes nigra as being characteristic for lowland, warmer, polluted sites, with seemingly a greater tolerance for nitrites. Amid the species from the genus Hydropshyche sp., there is a separation along the second axis between species that have a lower tolerances to decreased oxygen concentrations, like $H$. instabilis and $H$. pelucidulla as compared to $H$. fulvipes and $H$. incognita (Figure 3).

Due the high co-correlations between water pollutants and the natural selection of sites over an altitudinal gradient (and therefore the natural occurrence and variability of certain factors like water flow, oxygen and temperature), a second partial CCA was needed (Figure 4). The 
M. Pirvu and O. Pacioglu: Knowl. Managt. Aquatic Ecosyst. (2012) 407, 03
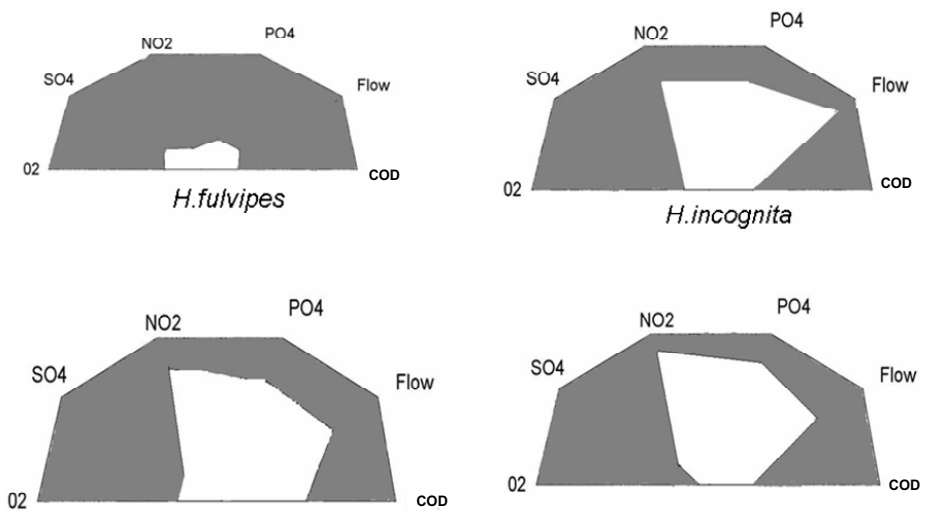

H.instabilis

H.pelucidulla

(a)

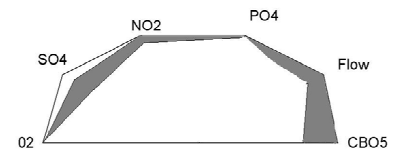

Rhyacophila tristis

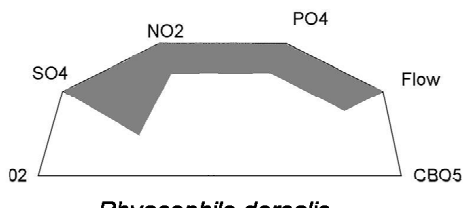

Rhyacophila dorsalis

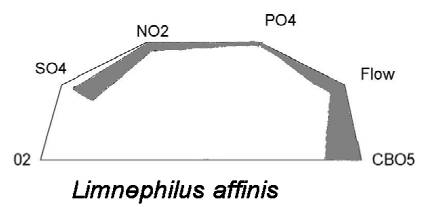

(b)

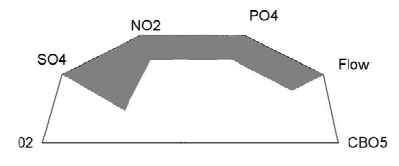

Sericostoma personatum
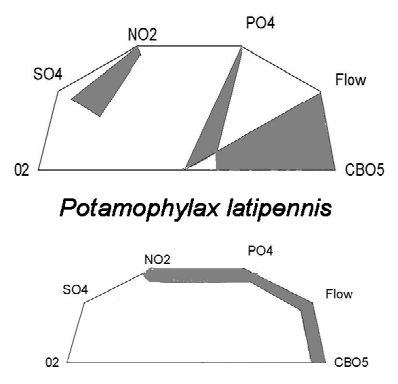

Ecllisopteryx madida

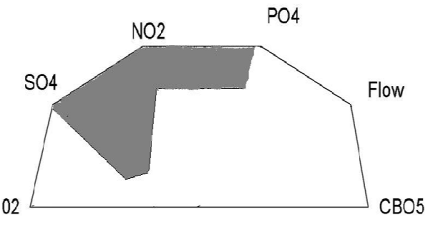

Limnephilus rhombicus

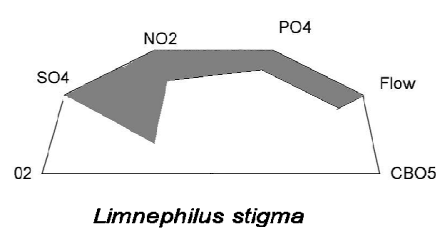

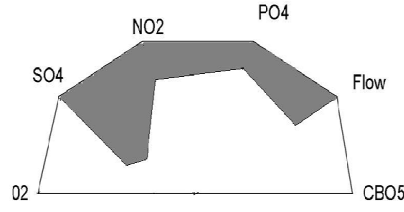

Limnephilus funatus

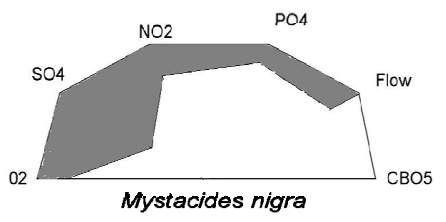

(c)

\section{Figure 6}

(a) Ecological profiles for common caddisflies based on polyhedral diagrams (Family Hydropsychidae).

(b) Ecological profiles for caddisflies characteristic to headwaters, based on polyhedral diagrams.

(c) Ecological profile of caddisflies species characteristic for lowland sites, based on polyhedraldiagrams. 


\section{Table IV}

Linear regression equations for the caddisflies species and physic-chemical variables selected by the Monte-Carlo test from the partial CCA ordinations. The step wise linear regression was applied to $\log (x+1)$ biotic and abiotic factors.

\begin{tabular}{|c|c|c|c|c|}
\hline Taxa & Equations & Adjusted $R^{2}$ & $F$ & $P$ \\
\hline H. fulvipes & $\begin{array}{c}135-0.65 \times \log (\text { Flow }+1) \\
+0.24 \times \log \left(\mathrm{PO}_{4}+1\right)\end{array}$ & 0.55 & 38.01 & $<0.001$ \\
\hline H. incognita & $\begin{array}{c}-117.1+0.38 \times \log \left(\mathrm{CBO}_{5}+1\right) \\
+0.37 \times p H\end{array}$ & 0.35 & 15.6 & $<0.001$ \\
\hline H. instabilis & $\begin{array}{c}-79+0.4 \times \log \left(\mathrm{O}_{2}+1\right) \\
+0.4 \times \log \left(\mathrm{SO}_{4}+1\right)\end{array}$ & 0.29 & 11.03 & $<0.001$ \\
\hline H. pelucidulla & $\begin{array}{c}-3.3+0.3 \times \log \left(\mathrm{O}_{2}+1\right) \\
-0.04 \times \log \left(\mathrm{SO}_{4}+1\right)\end{array}$ & 0.12 & 3.69 & 0.03 \\
\hline E. modida & $\begin{array}{c}-0.4+0.5 \times \log \left(\mathrm{O}_{2}+1\right) \\
-0.28 \times \log \left(\mathrm{SO}_{4}+1\right)\end{array}$ & 0.37 & 17.13 & $<0.001$ \\
\hline L. affinis & $\begin{array}{c}0.84+0.6 \times \log \left(\mathrm{O}_{2}+1\right) \\
-0.46 \times \log \left(\mathrm{SO}_{4}+1\right) \\
-0.25 \times \log \left(\mathrm{NO}_{2}+1\right)\end{array}$ & 0.71 & 47.6 & $<0.001$ \\
\hline P. latipennis & $\begin{array}{c}-0.77+0.5 \times \log \left(\mathrm{O}_{2}+1\right) \\
-0.35 \times \log \left(\mathrm{SO}_{4}+1\right)\end{array}$ & 0.44 & 22.6 & $<0.001$ \\
\hline R. dorsalis & $\begin{array}{c}-1.9+0.58 \times \log \left(\mathrm{O}_{2}+1\right) \\
-0.35 \times \log \left(\mathrm{SO}_{4}+1\right)\end{array}$ & 0.58 & 39.77 & $<0.001$ \\
\hline R. fasciata & $\begin{array}{c}0.25+0.48 \times \log \left(\mathrm{O}_{2}+1\right) \\
-0.42 \times \log \left(\mathrm{SO}_{4}+1\right) \\
-0.2 \times \log \left(\mathrm{NO}_{2}+1\right)\end{array}$ & 0.5 & 18.7 & $<0.001$ \\
\hline R. tristis & $\begin{array}{c}-0.17+0.55 \times \log \left(\mathrm{O}_{2}+1\right) \\
-0.34 \times \log \left(\mathrm{SO}_{4}+1\right) \\
-0.13 \times \log \left(\mathrm{NO}_{2}+1\right) \\
\end{array}$ & 0.49 & 18 & $<0.001$ \\
\hline R. personatum & $\begin{array}{c}-6.3+0.65 \times \log \left(\mathrm{O}_{2}+1\right) \\
-0.4 \times \log \left(\mathrm{SO}_{4}+1\right)\end{array}$ & 0.65 & 6.4 & $<0.001$ \\
\hline L. rhombicus & $\begin{array}{l}2.7-0.5 \times \log \left(\mathrm{O}_{2}+1\right) \\
+0.23 \times \log (\mathrm{Temp}+1)\end{array}$ & 0.34 & 14.8 & $<0.001$ \\
\hline L. Iunatus & $\begin{array}{c}1.9-0.54 \times \log \left(\mathrm{O}_{2}+1\right) \\
+0.3 \times \log (\mathrm{Temp}+1)\end{array}$ & 0.32 & 13.72 & $<0.001$ \\
\hline L. stigma & $\begin{array}{l}3.4-0.54 \times \log \left(\mathrm{O}_{2}+1\right) \\
+0.22 \times \log (\mathrm{Temp}+1)\end{array}$ & 0.37 & 17 & $<0.001$ \\
\hline M. nigra & $\begin{array}{c}1.01-0.51 \times \log \left(\mathrm{O}_{2}+1\right) \\
+0.2 \times \log (\mathrm{Temp}+1)\end{array}$ & 0.33 & 13.98 & $<0.001$ \\
\hline
\end{tabular}

pCCA run on only two environmental parameters (water velocity and solid suspensions) do explain 94\% from the variability of taxa (Flow $-F=33.5, p=0.002$, respectively solid suspensions $-F=40.3, p=0.002$, Monte Carlo test, 999 permutations) between sites. The ordination diagram reflects the preferences of three main groups of caddisflies: the first axis is explained by the water flow decreasing over an altitudinal transect, and with species characteristic from the genera Rhyacophila sp., S. personatum, P. latipennis and E. madida as having a preference for headwaters, with a higher water flow, highly oxygenated and low turbidity. The other group, represented by species from the genera Limnephilus sp. and M. nigra, provides a preference for lower altitude sites (e.g. more lentic like environments). The second axis is mainly a function of suspended solids, with the species from genus Hydropshyche sp. as having a preference for high water turbidity.

The linear regression equations (Table IV) reflect a better understanding in the attempt to find a quantitative relation amid their densities and the variability of environmental parameters. The stepwise linear regression method was employed, discarding the strong colinearity between factors and retaining only those that explain (in a both positive and negative way) the taxa densities with the highest strength.

The factors selected for the polyhedral diagrams (Figures 6a-6c) were selected from those having a significant influence on the caddisflies abundance in the multiple regression equations and not from those represented in the pCCA 's, due criteria like colinearity and 
overlapping ecological significance for explaining the existence of taxa. Therefore, the elements selected in order to explain the species status as being sensitive or tolerant organisms, were the sulphates, nitrites, phosphates and biological oxygen demand $\left(\mathrm{BOD}_{5}\right)$ (as factors directly related to pollution) and dissolved oxygen and water velocity (as factors related to pristine conditions).

The TWINSPAN dendrogram (Figure 5), based on pseudospecies frequencies, selected three main groups: those common in all sites ( $H$. fulvipes and H.inognita), as two other species from the same genus, but absent from the most downstream sites (Figure 3 ). The second dichotomy is based on the clustering of two completely different assemblages: those characteristic to the pristine headwaters (Rhyacophila sp., B. subnubilus, S. personatum, P. latipennis, $L$. affinis) and those characteristic to downstream sites, more lentic and more tolerant to pollution (Limnephilus sp., M. nigra) (Figures 3, 4).

\section{DISCUSSION}

The TWINSPAN analysis separated three groups: a common one, representative by four species from genus Hydropshyche sp. Two of them $(H$. fulvipes and $H$. incognita) are present in all sampling sites, all year round. As stated in Figure 6a, these two species seem to be the most tolerant taxa to water pollution and variability of physic-chemical parameters. Nevertheless, the other two species from the same genus $(H$. instabilis and $H$. pellucidula), seem to be separated mainly as a function of dissolved oxygen, being absent in the downstream sites. This finding is in accordance to Becker (1987), who found that the latter species is sensitive to low dissolved oxygen concentrations, and more characteristic to moderate polluted stretches of Rhine River. Bonada et al. (2004) suggested that $H$. instabilis is intolerant to low concentrations of dissolved oxygen. According to the regression equations, and separation by TWINSPAN dendrogram (Figure 5), the other two species of caddisflies are explained by different factors (e.g. sulphates) although their tolerances are not that relevant on the polyhedral diagrams (Figure 6a). Bonada et al. (2004) found that the species $\mathrm{H}$. instabilis is intolerant to high concentrations of sulphates.

Previous studies have reported different behaviours of species from genus Hydropsyche sp. to environmental changes as for their tolerances to the variability of the natural physicchemical parameters along the longitudinal profile of streams (Bonada et al. 2004; Ruse and Herrmann, 2000; Garcia et al., 2006). Moreover, the species from this genus have been showed as revealing preferences for certain lotic microhabitats, with a strong interspecific competition for food and space, and even a replacement of the taxa on a longitudinal profile of rivers (Edington, 1968; Hilldrew and Edington, 1979; Wallace and Meritt, 1980). The species $H$. pelucidulla and $H$. siltalai were found as coexisting in British streams, same for $H$. instabilis and $H$. siltalai (Hilldrew and Edington, 1979), their positions being explained by preferences for certain regimes of water temperature, flow, food, oxygen and pollution. Nevertheless, these species co-exist in the same riffles, revealing a strong interspecific tolerance with regard to competition for food and space. All the species from the genus Hydropshyche sp. were found as having a strong affinity for suspended sediments in water column, in accordance to previous studies (Basaguren and Orive, 1990; Mackay, 1980). This is mainly due their filter feeding behaviour, with nets capturing flowing organic matter in suspensions with different dimensions (Wallace and Merrit, 1980).

The headwaters were populated by a completely different suite of taxa as compared to the downstream sites, with three species from the genus Rhyacophila sp. characteristic only for the headwaters. The species $R$. tristis was found as being characteristic to the headwaters of Spanish rivers (Basaguren and Olive, 1990), as for English streams (Edington and Hilldrew, 1981) and being more sensitive than $R$. dorsalis to environmental pollution (Bonada et al., 2004), in accordance to our observations (Figure 6b). This latter species was found in headwaters and midstream with contrasting water qualities (Bonada et al., 2005), although in the polluted sites neither of these species being found, suggesting therefore a strong sensibility to high water quality. The coexistence of all three species of Rhyacophila sp. 
could be explained by a prey resource partitioning as suggested for sympatric caddisflies larvae previously (Malas and Wallace, 1977; Teague et al., 1985; Alstad, 1987). The species $B$. subnubilus is an univoltine species, generally found in low abundances, but representing an important percentage in the rivers secondary production and prefers moderate to high cold water flow stretches, well oxygenated and extremely sensitive to suspended sediments (Gunn, 1987; Anderwald, 1996). S. personatum is a shredder, extremely important in the leaf litter energy transfer from lower to higher trophic levels, and its presence and previous studies have regarded this taxa mainly from this point of view (Frieberg and Jacobsen, 1999; Iversen, 1974, 1979). Bonada et al. (2004) found this genus as sensitive to water pollution, in accordance to our observations. $P$. latipennis and $E$. madida, along with $L$. affinis are limnephilids that provide a strong intolerance to water pollution (Figure 6b). In what concerns $P$. latipennis, our observations are in accordance to those of Bonada et al. (2004), who described this taxa as one characteristic for pristine river stretches, intolerant for most of the inorganic pollutants, including heavy metals (Vuori, 1993). Bonada et al. (2005) found this latter species as being a rare one in the trichopteran assemblages from Spanish rivers, a common situation in this survey, and same for $B$. subnubilus. $L$. affinis is a species that was found in this survey only in the headwaters, although its relatives from the same genus were found confined further downstream. This species was found as having a strong dependency of life cycle to the ambient temperature (Gislason, 1978) and its presence could be explained by preferences for colder, highly oxygenated river stretches, like for the headwaters of this river.

The third group, comprising species appurtenant to genus Limnephilus sp. and M. nigra (Family Leptoceridae) were found only in $\mathrm{S}_{2}$, after the confluence with a much cleaner tributary, the Tismana River (Figure 1). The pCCA suggest this group as being characteristic to lowland sites (Figure 4), with a lower water velocity and much warmer then the headwaters, low suspended sediments and high tolerance to nitrites. However, the tolerance for nitrites is not significantly different as compared to the limnephilids and $B$. subnubilus tolerance levels from headwaters, and therefore not noticeable as well on the polyhedral diagrams (Figure 6c). The regression equations explain the density of these taxa as mainly a function of oxygenated waters (negatively) and higher temperatures (positively). Considering that these taxa were found only in this site $\left(S_{2}\right)$, after the confluence with a cleaner tributary, it could be reasonable to explain the lack of tolerances for higher concentrations of pollutants, but rather a preference for lower oxygen and higher temperature than those registered in the upstream sites on the grounds of their spatial location. The cleaner waters of Tismana River are providing better conditions for the existence of this community and explain its absence from more downstream sites $\left(S_{1}\right)$, where only hydropsychids was found. Therefore, the results suggest that this community of caddisflies is rather influenced by natural variance of physic-chemical factors (e.g. preference for more lentic waters and higher temperature) than rather by the increase in pollutants concentrations and as being massively influenced by the confluence of the main stem of polluted Jiu River with the cleaner tributary of Tismana River.

As stated in previous studies (Anderson and Klubnes, 1983; Basaguren and Olive, 1990; Boon, 1979; Edington, 1968; Hilldrew and Edington, 1979) the longitudinal habitat partitioning, different eco-physiological requirements, inter- and intraspecific competition for food and space are important drivers in species co-existence and/or replacement of taxa from headwaters toward lowlands.

\section{CONCLUSIONS}

The investigated species of caddisflies from the River Jiu seem to be influenced by a synergic combination of natural physic-chemical parameters (e.g. decrease of dissolved oxygen, water velocity, increase of suspended solids and temperature) and pollutants ( $\mathrm{N}$ species, phosphates, sulphates, BOD5, TOC, conductivity) on a longitudinal transect. One of the three depicted "clusters" may actually comprise the dominant and most frequent one group, the hydropsychids, that are very widespread and tolerant to both natural and human induces disturbances. The other two clades, separated by a long distance, and inhabiting habitats with 
different characteristics, might actually comprise two groups of caddisflies who are not that different with respect to their toleration to pollutants, but rather employing different habitat requirements. The positioning of the latter group is perhaps massively influenced by the junction of the polluted main stem of River Jiu with the cleaner tributary of Tismana River.

\section{REFERENCES}

Alstad D.N., 1987. Particle size, resource concentration and the distribution of the net spinning caddisflies. Oecologia, 71, 525-531.

Anderson T. and Klubnes R., 1983. The life histories of Hydropsyche siltalai (Dohler, 1963) and Hydropsyche pellucidula (Curtis, 1834) (Trichoptera, Hydropsychidae) in a west Novergian river. Aquatic Insects, 5, 51-62.

Anderwald P.H., 1996. A qualitative description of the life cycle and density regulation of Brachycentrus subnubilus in the Austrian Danube. Archive fur Hydrobiologie, Supplementband, 10, 417-424.

Basguren A. and Orive E., 1990. The relationship between water quality and caddisfly assemblage structure in fast running rivers. The River Cadagua basin. Environmental Monitoring and Assessment, $15,35-48$.

Becker G., 1987. Net building behavior, tolerance and development of two caddisfly larvae from the river Rhine (Hydropsyche contubernalis and H .pellucidula) in relation to oxygen content. Oecologia, 73, 242-250.

Birks H.J.B., Line J.M., Juggins S., Stevenson A.C. and ter Braak C.J.F., 1990. Diatoms and pH reconstruction. Philos. Trans. Roy. Soc. Lond., 327, 263-278.

Bonada N., Munoz-Zamora C., Rierdevall M. and Prat N., 2004. Ecological profiles of caddisfly larvae in Mediterranean streams: implications for bioassement methods. Environmental Pollution, 132, 509-521.

Bonada N., Munoz-Zamora C., Rierdevall M. and Prat N., 2005. Ecological and historical filters constraining spatial caddisfly distribution in Mediterranean rivers. Fresh. Biol., 50, 781-797.

Boon P.J., 1979. Studies on the spatial and temporal distribution of larval Hydropsychidae in the north Tyne River system (Northern England). Arch. Hydrobiol., 85, 336-359.

Camargo J.A., Gonzalo C. and Alonso Á., 2011. Assessing trout farm pollution by biological metrics and indices based on aquatic macrophytes and benthic macroinvertebrates: A case study. Ecological Indicators, 11, 911-917.

Castillo L.E., Martínez E., Ruepert C., Savage C., Gilek M., Pinnock M. and Solis E., 2006. Water quality and macroinvertebrate community response following pesticide applications in a banana plantation, Limon, Costa Rica. Science of The Total Environment, 367, 418-432.

Cupža D., Covaciu-Marcov S.D., Sucea F. and Hercup R., 2010. Using macrozoobenthic invertebrates to asses the quality of some aquatic habitats from Jiului Gorge National Park (Gorj County, Romania). Biharean Biologist, 4, 109-119.

Dohet A., 2002. Are caddisflies an ideal group for the biological assessment of water quality in streams? Proceedings of the 10th International Symposium on Trichoptera.

Dumbravã-Dodoacã M. and Petrovici M., 2010. The influence of the anthropic activities on the benthonic macroinvertebrates community existing in the Jiu and Jiul de Vest rivers, south west of Romania. AACL Bioflux, 3, 133-140.

Edington J.M., 1968. Habitat preferences in net-spinning caddish larvae with special reference to the influence of water velocity. J. Animal Ecology, 37, 675-692.

Fairchild M.P. and Holomuzki J.R., 2002. Spatial variability and assemblage structure of stream hydropschid caddisflies. J. North American Benthological Society, 21, 576-588.

Frieberg N. and Jacobsen D., 1999. Variation in growth of the detritivore shredder Sericostoma personatum (Trichoptera). Fresh. Biol., 42, 625-635.

Garcia A.R., Herrera A.F.G and, Romero-Ferreras A., 2006. Distribution of Trichoptera communities in the Hargargonta catchments (Los Alcornocales, Natural Park, SW Spain). Int. Rev. Hydrobiol., 91, 781-785.

Gislason G.M., 1978. Life cycle of Limnephilus affinis (Trichoptera: Limnephilidae) in Iceland and in Northumberland, England. Verrhsung Intern. Verein. Limnol., 20, 2622-2629.

Gunn R.J.M., 1985. The biology of Brachycentrus subnubilus Curtis (Trichoptera) in River Frome. Hydrobiologia, 3, 133-140.

Hammer Ø., Harper D.A.T and Ryan P.D., 2001. Paleontological Statistics software package for education and data analysis. Palaeontologia Electronica, 4, 1-9. 
Hildrew A., 1986. Aquatic insects: patterns in life history, environment and community structure. Proceedings of the 3rd European Congress of Entomology. Amsterdam.

Hildrew A. and Edington J.M., 1979. Factors facilitating the coexistence of hydropsychid caddis larvae (Trichoptera) in the same river system. Journal of Animal Ecology, 48, 557-576.

Illies J. and Botosaneanu L., 1963. Problemes et metodes de la classification et de la zonation ecologiques des eaux courantes, considerees surtout du point de vue faunistique. Mitteilungen der Internationalen Vereinigung fur Teoretische und Angewandte Limnologie, 12, 1-57.

Iversen T.M., 1974. Ingestion and growth in Sericostoma personatum (Trichoptera) in relation to the nitrogen content of ingested leaves. Oikos, 25, 278-282.

Iversen T.M., 1979. Laboratory energetic of larvae of Sericostoma personatum (Trichoptera). Ecography, 2, 1-5.

MacCausland A. and McTammany M.E., 2007. The impact of episodic coal mine drainage pollution on benthic macroinvertebrates in streams in the Anthracite region of Pennsylvania. Environ. Pollut., $149,216-226$.

Mackay R.J., 1984. Life History patterns of Hydropsyche bronta and Hydropsyche morosa (Trichoptera: Hydropsychidae) in summer warm rivers of southern Ontario. Can. J. Zool., 62, 271-275.

Malas D. and Wallace J.B., 1977. Strategies of coexistence in three species of net-spinning caddisfly (Trichoptera) in second order southern Appalachian streams. Can. J. Zool., 55, 1829-1840.

Murphy J.H., Giller P.S. and Horan M.A., 1998. Spatial scale and the aggregation of stream macroinvertebrates associated with leaf packs. Fresh. Biol., 39, 325-337.

Resh V.H., 1992. Recent trends in the use of Trichoptera in water quality monitoring. Proceedings of the seventh International Symposium on Trichoptera.

Resh V.H., Brown A.V., Covich A.P., Gurtz M.E., Li H.W., Minshall G.W., Reice S.R., Sheldon A.L., Wallace J.B. and Wissmar R., 1988. The role of disturbance in stream ecology. Journal of the North American Benthological Society, 7, 433-455.

Ruse L.P. and Hermann S.J., 2000. Plecoptera and Trichoptera species distribution related to environmental characteristics of the metal-polluted Arkansas river, Colorado. American Naturalist, 60, 57-65.

Shaw PJ., 2003. Principal Component Analysis. Multivariate statistics for the Environmental Sciences. In: Arnold H. (ed.) Oxford University Press Ink, New York, 92-124.

Shiels D.R., 2010. Implementing landscape indices to predict stream water quality in an agricultural setting: An assessment of the Lake and River Enhancement (LARE) protocol in the Mississinewa River watershed, East-Central Indiana. Ecological Indicators, 10, 1102-1110.

Teague S.A., Knight A.W. and Teague B.N., 1985. Stream macrohabitat selectivity, resource partitioning and niche shifts in grazing caddishfly larvae. Hydrobiologia, 128, 3-12.

ter Braak C.J.F. and Barendregt L.G., 1986. Weighted averaging of species indicator values: its efficiency in environmental calibration. Mathematical Biosciences, 78, 57-72.

Townsend C. and Hildrew A., 1994. Species traits in relation to a habitat template for river system. Fresh. Biol., 31, 265-275.

Townsend C.R., Scarbrook M.R. and Doledec S., 1997. Quantifying disturbance in streams: alternative measures of disturbance in relation to macroinvertebrate species traits and species richness. Journal of the North American Benthological Society, 16, 531-544.

Usseglio-Polaterra P., Bournaud M., Richoux P. and Tachet H., 2000. Biological and ecological traits of benthic freshwater macroinvertebrates : relationships and definition of groups with similar traits. Fresh. Biol., 43, 175-205.

Vannote R.L., Minshall G.W., Cumins K.W., Sedell J.R. and Cushing C.E., 1980. The river continuum concept. J. Fishery Aquatic Sciences, 37, 130-137.

Vuori K.M., 1993. Influence of water quality and feeding habits on the whole body metal concentrations in lotic trichopteran larvae. Limnologica, 23, 301-308.

Wallace J.B. and Merritt R.W., 1980. Filter feeding ecology of aquatic insects. Annu. Rev. Entomol., 25, 103-132.

Wallace I.D., Wallace B., Philipson G.N., 2003. Case-bearing caddis larvae of Britain and Ireland, Freshwater Biological Association, UK, $70 \mathrm{p}$.

Waringer J. and Graf W., 1997. Atlas der Österreichischen Köcherfliegenlarven. Facultas Universitätsverlag, Wien, $120 \mathrm{p}$.

Wildsmith M.D., Rose T.H., Potter I.C., Warwick R.M. and Clarke K.R., 2011. Benthic macroinvertebrates as indicators of environmental deterioration in a large microtidal estuary. Marine Pollution Bulletin, $62,525-538$.

Wright J.F., Sutcliffe D.W. and Furse M., 2000. Assessing the biological quality of fresh waters. RIVPACS and other techniques, Freshwater Biological Association, UK, 356 p. 